\title{
Partisipasi Masyarakat Lokal Dalam Pengembangan Pariwisata Di Desa Jatiluwih, Kabupaten Tabanan, Bali
}

I Gusti Agung Fajar Wisnu Wardana a, 1, I Made Adikampana a, 2

${ }^{1}$ fajarwisnu1605@gmail.com, 2 adikampana@unud.ac.id

a Program Studi S1 Destinasi Pariwisata, Fakultas Pariwisata,Universitas Udayana, Jl. Dr. R. Goris, Denpasar, Bali 80232 Indonesia

\section{Abstract}

Tourism development should involve the local community as one of strakeholders in its management. In the management of tourist villages, local community should be active in tourism activities to gain the benefits . Therefore local communities also have the right to be able to earn the economic benefits equitably. This study aims to determine the participation of local communities in the management of tourism activites in the Jatiluwih Village, Bali. This research is important because local community participation in tourist village can determine sustainable development

The research methodology used in this study is a qualitative research, with observation, semi-structured interviews, and documentation as well as using the concept of a tourism village and community participation theory to analyze the problems in the field.

The result shows that decision-making in local community participation is still lacking. They have chance to listened or hearded but their opinion not necesseraliy considered. Benefits received by the local community from tourism activities are the community has begun to get the right share from the tourism development of their village.

Keywords : Community Participation, Tourism Development, Jatiluwih Village

\section{PENDAHULUAN}

Jatiluwih merupakan sebuah desa yang terletak di Kecamatan Penebel, Kabupaten Tabanan, Bali, merupakan sebuah desa wisata yang memiliki panorama alam yang indah dan identik dengan sawah berundak yang mengikuti kontur tanah yang bertingkat dengan latar belakang Gunung Batukaru. Subak Jatiluwih dijadikan sebagai Daya Tarik utama dalam pengembangan Desa Wisata Jatiluwih. Jatiluwih berada pada ketinggian 700 meter diatas permukaan laut sehingga kondisi udaranya tergolong sejuk dan masih terbebas dari polusi, terdapat curah hujan signifikan di daerah ini, suhu tahunan adalah rata-rata $19.0^{\circ} \mathrm{C}$. ( Pemerintah Kabupaten Tabanan 2006)

Keindahan alam yang terdapat di daya tarik wisata Jatiluwih ini membuat The United Nations Educational, Scientific and Cultural Organization (UNESCO) menetapkan kawasan ini menjadi Situs Warisan Budaya (WBD) pada tanggal 29 juni 2012. Pengusulan warisan dunia kepada UNESCO dimulai sejak tahun 2003. Setelah melakukan proses yang cukup panjang serta memenuhi semua syarat maka WBD Bali mengusulkan kepada UNESCO dan resmi ditetapkan sesuai dengan prasasti tertanggal 29 Juni 2012 (Widari,2015). Kunjungan wisatawan ke Desa Wisata Jatiluwih setelah penetapan subak sebagai WBD, mengalami peningkatan. Demikian juga dengan pendapatan masyarakat yang diterima secara langsung dari berkembangnya lapangan kerja dan kesempatan usaha meningkat. Namun peningkatan tersebut belum memberikan manfaat ekonomi yang menyeluruh kepada masyarakat lokal. Hanya masyarakat yang bekerja di badan pengelola dan membuka usaha di pariwisata yang mendapat manfaat langsung dari pengembangan Desa Wisata. Namun, terdapat permasalahan-permasalahan seperti akses jalan yang rusak, tidak adanya tempat parkir yang memadai hingga kurangnya partisipasi masyarakat lokal dalam kegiatan pariwisata yang akan dapat memicu penurunan jumlah wisatawan. Menurut Tikson (2001) partisipasi merupakan sebuah proses dimana masyarakat sebagai stakeholder, terlibat mempengaruhi dan mengendalikan pembangunan pariwisata di tempat mereka masing-masing. Dalam pengelolaan desa wisata, masyarakat lokal turut aktif dalam kegiatan pariwisata sehingga mendapatkan keuntungan dari kegiatan pariwisata tersebut. Partisipasi masyarakat dalam setiap pembangunan desa merupakan salah satu kunci keberhasilan pembangunan. Salah satu cara untuk meningkatkan partisipasi masyarakat lokal dalam kegiatan pariwisata di desanya adalah melibatkan masyarakat dalam proses pengambilan keputusan dan mendapatkan manfaat pariwisata tersebut. Masyarakat 
Jatiluwih kurang berpartisipasi dalam pengembangan desanya. Keterlibatan masyarakat dalam pengelolaan desa wisatanya masih kurang, mulai dari tahap persiapan, perecanaan, operasional, pengembangan dan pengawasan (Prasiasa, 2010).

Berdasarkan hal tersebut diperlukan penelitian terkait partisipasi masyarakat dalam proses pengambilan keputusan dan manfaat yang diterima masyarakat dari pembangunan pariwisata di Desa Jatiluwih. Karena kedua komponen tersebut merupakan bagian penting dalam pembangunan pariwisata berbasis masyarakat.

\section{TINJAUAN PUSTAKA}

Penelitian ini menggunakan beberapa pedoman konsep dan teori untuk menganalisis data yang didapat di lapangan, yaitu:

Desa wisata. Suatu desa dijadikan sebagai desa wisata harus memiliki persyaratan-persyaratan antara lain memiliki objek-objek yang menarik untuk ditawarkan (attractions), mudah dijangkau dengan alat transportasi (accessibilities), dan tersedia sarana pariwisata (amenities) seperti akomodasi, restoran/rumah makan (Nuryanti, 1993). Dalam aktivitas pariwisata di desa wisata tersebut, masyarakat lokal dalam perencanaan pengelolaan ataupun pembangunan harus berperan aktif untuk mengelola desa wisata tersebut. Hal itu sesuai dengan konsep Community Based Tourism (CBT). Untuk melihat partisipasi masyarakat Timothy (1999) mengemukakan ada dua perspektif untuk melihat partisipasi masyarakat dalam pariwisata. Kedua perspektif tersebut adalah (1) partisipasi masyarakat lokal dalam proses pengambilan keputusan yaitu masyarakat diajak pada suatu rapat dalam mengambil keputusan dan keputusannya tersebut dipertimbangkan. (2) berkaitan dengan manfaat yang diterima masyarakat dari pembangunan pariwisata yaitu dengan adanya kegiatan pariwisata di desa mereka, maka manfaat sosial ekonomi dapat dirasakan dari adanya kegiatan tersebut.

\section{METODE}

Penelitian ini dilakukan di Desa Jatiluwih, Kabupaten Tabanan, Bali. Adapun ruang lingkup penelitian yang digunakan yaitu :

1. Partisipasi masyarakat dalam proses pengambilan keputusan.
2. Pembagian manfaat pariwisata bagi masyarakat lokal

Jenis dan sumber data dalam penelitian ini menggunakan jenis data kualitatif seperti uraian kalimat hasil wawancara yang ditulis secara deskriptif dan dua sumber data yaitu sumber data primer serta sumber data sekunder. Dalam pengumpulan data menggunakan tiga teknik, yaitu: observasi, wawancara semi terstrukstur dan dokumentasi (Sugiyono, 2014). Untuk menentukan informan menggunakan teknik purposive sampling, dan snowball technique yaitu peneliti menetapkan lebih awal siapa yang menjadi sampelnya awalnya dan ketika penelitian berlangsung, peneliti meminta informan untuk mengarahkan ke informan lainnya (Mukthar, 2013).

Teknik analisis data dalam penlitian ini menggunakan teknik analisis data deskriptif kualitatif yaitu data wawancara dalam penelitian adalah sumber data utama yang menjadi bahan analisis data untuk menjawab masalah penelitian. Analisis data dimulai dengan membuat transkip hasil wawancara dengan cara memutar kembali rekaman wawancara kemudian menuliskan kata-kata yang sesuai dengan apa yang ada direkaman tersebut. Setelah peneliti menulis hasil wawancara ke dalam transkip, selanjutnya peneliti membuat reduksi data dengan cara abstraksi, yaitu mengambil data yang sesuai dengan konteks penelitian dan mengabaikan data yang tidak diperlukan.

\section{HASIL DAN PEMBAHASAN}

a. Profil pariwisata Desa Jatiluwih, Kabupaten Tabanan, Bali

Desa Jatiluwih berjarak 27 kilometer dari ibu kota Kabupaten Tabanan atau 48 kilometer dari ibu kota Provinsi Bali (Denpasar) dapat dijangkau dengan alat transportasi berupa kendaraan umum dan kendaraan pribadi.

Sejarah Desa Jatiluwih hingga saat ini belum dapat ditemukan di suber tertulis, tetapi hanya dari penuturan masyarakat desa yang tua dan sesepuh di desa itu.menurut penuturan itu nama Desa Jatiluwih berasal dari kata jaton ( yang berarti jimat) dan luwih ( yang berarti bagus). Bila disatukan maka Jatiluwih berarti jimat yang bagus. Namun ada juga yang menuturkan bahwa Desa Jatiluwih dahulu terdapat kuburan binatang purba yaitu burung 
Jatayu. Seiring berjalannya waktu nama Jatayu berubah lafal menjadi jaton ayu (jaton berarti jimat, ayu berarti bagus) dan akhirnya menjadi Jatiluwih. (Penebelofficer,2015)

Jatiluwih terkenal dengan keindahan alam berupa sawah teraseringnya yang luas dan berundak-undak sehingga menjadi salah satu tujuan wisata terbaik di Bali. Aktifitas petani di Jatiluwih adalah salah satu daya tarik tersendiri bagi wisatawan, pada umumnya kegiatan petani di sawah masih menggunakan cara-cara dan alat-alat tradisional untuk menggarap sawahnya seperti; mencangkul, nampadin (membersihkan pematang sawah), ngelampit (membajak sawah), melasah (meratakan tanah sawah), nandur (menanam padi), dan lain sebagainya. (Widari,2015)

Aktifitas pertanian tersebut menjadi salah satu daya tarik tersendiri dan dijadikan sebagai obyek fotografi oleh wisatawan. Selain itu di Jatiluwih juga terdapat aktifitas wisata seperti hiking dan cycling. Untuk dapat mendukung kegiatan pariwisata, di Jatiluwih terdapat sarana pariwisata seperti penginapan atau pondok wisata, cafe, dan warung atau rumah makan ataupun restoran yang khusus menyajikan makanan khas dengan beras merah dari hasil pertanian di Jatiluwih. Untuk mengunjungi daya tarik wisata Jatiluwih direkomendasikan antara pukul 8.00 pagi sampai sore hari sekitar pukul 5.00. Karena antara pukul-pukul tersebut aktifitas petani paling mudah untuk dijumpai. Curah hujan yang cukup tinggi membuat wisatawan dihimbau menyediakan payung. Untuk bisa menikmati panorama alam Jatiluwih dengan sawah terasering yang hijau dan indah, wisatawan biasanya akan direkomendasikan untuk mengunjungi Jatiluwih diantara bulan Februari sampai dengan bulan April. Hal tersebut dikarenakan pada bulan-bulan tersebut tanaman padi akan tumbuh tinggi, hijau dan menguning. Waktu terbaik lainnya juga terdapat di sekitar bulan Juni dan Juli, karena pada saat itu tanaman padi akan siap di panen dan aktifitas memanen oleh petani akan banyak dijumpai. (Widari,2015)

b. Partisipasi masyarakat lokal Desa Jatiluwih dalam pengambilan keputusan.

Pembangunan dan perkembangan pariwisata perdesaan, aspek penting yang perlu mendapat perhatian adalah membuat desa tersebut menjadi sebuah produk pariwisata yang berkelanjutan (Kementerian Pariwisata dan Ekonomi Kreatif, 2011). Untuk mencapai hal tersebut harus dilakukannya sebuah terobosan agar pariwisata yang ada di Desa tersebut dapat dinikmati dari generasi ke generasi. Salah satu kunci dari keberhasilan suatu Desa wisata adalah dilibatkannya Masyarakat lokal dalam setiap kegiatannya. Baik pada pembangunan maupun pengembangannya. Sehingga Masyarakat Lokal yang ada didalamnya dapat merasakan manfaat dari adanya suatu Desa Wisata.

Perlunya melibatkan masyarakat dalam pengambilan keputusan dengan mengakomodasi keinginan dan tujuan masyarakat lokal dalam pembangunan serta kemampuannya dalam menyerap manfaat pariwisata. Dengan demikian, perencanaan pembangunan pariwisata harus mengakomodasi keinginan dan kemampuan masyarakat lokal untuk berpartisipasi serta memperoleh nilai manfaat yang maksimal dari pembangunan pariwisata (Timothy, 1999).

Menurut Bapak Nengah Sulatra yang merupakan petani Di Desa Jatiluwih berpendapat bahwa Masyarakat di Desa Jatiluwih sangat kurang mendapat soialisasi program program kepariwisataan. Memang terdapat beberapa sosialisasi program program kepariwisataan dan mereka mendapat kesempatan mendengarkan dan didengarkan namun belum tentu pandangan mereka dapat diterima dan langsung ditanggapi oleh pemerintah.

Beliau berharap agar desa mereka terus mendapatkan soialisasi dan pelatihan pelatihan agar masyarakat mengetahui apa yang harus dilakukan untuk memajukan pariwisata di desa mereka. Dengan diterima dan ditanggapi secara langsung oleh pemerintah akan menjadi salah satu faktor pendukung peningkatan partisipasi masyarakat karena keinginan mereka didengar.

Dengan mayoritas penduduk Desa Jatiluwih sebagai petani tentunya mereka disibukan dengan aktivitas pertanian mereka disawah. Pada tahun 2015 tercatat sebanyak 395 orang tergabung dalam anggota subak Desa Jatiluwih. Belum lagi masyarakat Desa Jatiluwih disibukkan dengan upacara upacara keagamaan yang ada di desanya. Hal ini menyebabkan partisipasi masyarakat kurang dalam program program sosialisasi kepariwisataan di desanya. Padahal di Desa Jatiluwih masih sangat kurang. Sosialisasi 
sosialisasi tersebut memastikan keputusan tersebut tidak hanya sosialisasi tapi lebih kepada kemampuan masyarakat lokal untuk ikut dalam setiap proses pengembangan desa wisata. Selain itu juga berguna bagaimana mereka mengelola dan memahami arti pentingnya pembangunan pariwisata yang berkelanjutan bagi generasi penerus mereka.

Berdasarkan catatan buku tamu kantor

Kepala Desa Jatiluwih tercatat ada enam kali sosialisasi program kepariwisataan. Adapun sosialisasi kepariwisataan di Desa Jatiluwih. Pada tahap ini masyarakat setempat memang dilibatkan dalam sosialisasi program-program kepariwisataan tetapi masyarakat tidak memiliki kekuasaan untuk menolak program program yang telah ditetapkan pemerintah. dalam kaitannya dengan Otonomi Daerah maka peran serta dan tanggung jawab masyarakat dalam pengelolaan sumberdaya budaya harus lebih ditingkatkan. Hal ini penting sebagai usaha menuju pengelolaan sumberdaya budaya yang berbasis masyarakat (community based management).

Berdasarkan pembahasan tersebut dapat dikatakan partisipasi masyarakat dalam pengambilan keputusan masih lemah. Hal tersebut dikarenakan masyarakat lokal mendapat kesempatan mendengarkan dan didengarkan namun belum tentu dipertimbangkan dalam pengambilan keputusannya.

\section{c. Pembagian manfaat pariwisata bagi masyarakat lokal \\ Semenjak ditetapkannya Desa Jatiluwih} menjadi situs warisan dunia oleh UNESCO pada tanggal 29 juni 2012 membuat wisatawan yang berkunjung meningkat. Dengan harga tiket masuk sebesar Rp. 20.000,00 untuk wisatawan mancanegara dan Rp. 10.000,00 untuk wisatawan nusantara. Kontribusi badan pengelola Desa wisata Jatiluwih terhadap masyarakat hanya pada keringanan pembebasan iuran iuran untuk upacara adat yang diacarakan di desa mereka.

Wisatawan yang berkunjung ke Desa wisata Jatiluwih pada umumnya aktivitas yang mereka lakukan adalah trekking di sawah dan menikmati makan siang di restaurant yang tersedia disana. Untuk trekking wisatawan berajalan melewati jalur yang telah dibuatkan oleh badan pengelola yaitu melewati sawah sawah milik warga. Untuk sawah sawah yang dilewati trekking oleh wisatawan badan pengelola memberikan kontrak kepada pemilik sawah sebesar dua juta rupiah per tahun dan dikontrak selama sepuluh tahun. Sebanyak 15 orang petani yang mendapat keuntungan dari jalur trekking tersebut. Namun sawah yang tidak dilalui trekking tidak mendapatkan uang kontrak tersebut. Jadi petani yang tidak mendapatkan kontrak dari jalur trekking tersebut hanya mengandalkan pendapatan dari hasil panen sawah mereka.

Perkembangan Pariwisata di Desa Jatiluwih memberikan dampak pada lapangan pekerjaan. Seiring dengan meningkatnya jumlah kunjungan wisatawan diiringi juga dengan meningkatnya sarana dan prasarana penunjang pariwisata. Sarana pelengkap adalah fasilitas yang disediakan untuk melengkapi sarana pokok, yang ditujukan agar wisatawan lebih lama tinggal di daerah tujuan wisata.Sarana pariwisata yang berkembang untuk memenuhi kebutuhan wisatawan adalah restaurant, warung makan, home stay dan villa. Namun terdapat juga sarana pendukung seperti trekking, cycling dan ATV.

Trekking merupakan sebuah aktivitas menyusuri jalur dengan keasrian alamnya yang masih terjaga. Di Desa Jatiluwih terdapat trekking melewati jalur persawahan dimana wisatawan dapat menikmati berjalan dengan pemandangan persawahan yang terbentang luas. Pada jalur trekking wisatawan akan melewati jalan setapak dan disuguhkan pemandangan petani mengolah sawahnya dan dapat melihat kandang sapi. Sapi tersebut sengaja diletakkan di persawahan agar petani Desa Jatiluwih lebih mudah untuk menggunakan sapinya untuk mengolah sawahnya. Trekking di Desa Jatiluwih dibawah badan pengelola Desa Jatiluwih, Sehingga pendapatan dari trekking tersebut masuk ke badan pengelola Desa Jatiluwih. Jumlah karyawan yang bekerja menjadi guide trekking sebanyak 4 orang. Dalam 1 hari terdapat 2 orang yang bertugas menjadi guide ditempat trekking tersebut. Guide trekking disini menggunakan sistem piket. Jika dilihat dari jumlah kunjungan wisatawan yang berkunjung ke Desa Jatiluwih, jumlah guide trekking masih sangat kurang. Menurut wawancara dengan Badan pengelola hal yang menyebabkan kurangnya jumlah guide adalah masih sangat minimnya pandangan masyarakat untuk bekerja di sektor pariwisata. Hal ini 
dikarenakan mereka tidak memiliki skill dalam bidang pariwisata terlebih dalam bahasa asing.

Sarana pendukung pariwisata lainnya adalah ATV. Wisatawan yang berkunjung ke Desa jatiluwih dapat menikmati pemandangan desa Jatiluwih menggunakan kendaraan beroda empat tersebut sehingga dapat melihat keadaan desa secara keseluruhan. Namun untuk menyewa ATV tersebut wisatawan harus mencari tempat penyewaanya hal ini dikarenakan ATV tidak berada dibawah badan pengelola Desa jatiluwih.

Di Desa jatiluwih terdapat aktivitas bersepeda dengan mengelilingi bagian bagian Desa Jatiluwih dan menikmati hamparan sawah yang indah. Wisatawan yang berkunjung ke Desa jatiluwih dapat menyewa sepeda beserta dengan guide-nya untuk menjelaskan tentang Desa jatiluwih. Terdapat sekitar 2 sampai 3 orang yang memiliki usaha penyewaan sepeda di Desa Jatiluwih.

Pendapatan yang diterima masyarakat Desa jatiluwih berasal dari usaha usaha yang berkaitan dengan pariwisata maupun pengelolaan desa wisata. Setelah ditetapkannya subak menjadi situs warisan dunia pendapatan pengusaha pariwisata mengalami peningkatan.Wisatawan yang berkunjung ke Desa Wisata Jatiluwih umumnya untuk menikmati keindahan terasering sawah serta makan siang. Ada juga wisatawan yang datang untuk melakukan kegiatan wisata seperti trekking, bersepeda maupun menikmati suasana pedesaan dengan mengendarai ATV. Meningkatnya jumlah kunjungan wisatawan memberi imbas terhadap kelangsungan usaha yang dikelola oleh pengusaha pariwisata.

Tiket masuk ke Desa Jatiluwih sebelum penetapan subak sebagai situs warisan dunia adalah sebesar Rp. 10.000,00 untuk wisatawan lokal dan Rp. 20.00,00 untuk wisatawan mancanegara. Setelah penetapan subak sebagai Warisan Budaya Dunia, dari pendapatan kotor (bruto) yang diterima, setelah dikurangi asuransi maka diperoleh pendapatan bersih (netto). Selanjutnya, pendapatan netto didistribusikan untuk manajemen operasional $15 \%$, pengembangan $10 \%$, promosi $5 \%$, dan badan pengelola $10 \%$. Kemudian, dari sisa pendapatan tersebut didistribusikan lagi untuk Pemerintah Daerah Kabupaten Tabanan 45\% dan untuk desa 55\%. Pendapatan yang diterima oleh desa, didistribusilkan lagi, yaitu untuk Desa Dinas 25\%, Desa Adat Jatiluwih 30\%, Desa
Adat Gunungsari 20\%, Subak Jatiluwih 21\%, Subak Abian Jatiluwih 2\%, dan Subak Abian Gunungsari 2\%.

Pendapatan pengelolaan Daya Tarik Wisata Jatiluwih bersumber dari karcis masuk, karcis parkir, dan pendapatan lain-lain. Retribusi tempat rekreasi dan parkir berdasarkan Keputusan Ketua Umum Badan Pengelola Daya Tarik Wisata Jatiluwih Nomor 02 Tahun 2014.

Pendapatan yang diterima dari pengelolaan desa wisata oleh desa adat, dipergunakan untuk membiayai upacara keagamaan. Dalam penyelenggaraan upacara keagamaan di pura, biasanya masyarakat dikenakan sejumlah iuran wajib sebesar Rp. $50.000,00$. Namun, dengan adanya pembagian pendapatan, masyarakat Desa Jatiluwih tidak perlu lagi membayar iuran wajib tersebut. Bagi masyarakat setempat, hal ini dapat meringankan biaya yang harus dikeluarkan untuk kegiatan upacara keagamaan. Jadi dapat dikatakan secara tidak langsung, masyarakat telah mendapat manfaat dari adanya kegiatan pariwisata di desa mereka meskipun jumlahnya bisa dikatakan sedikit. 


\section{SIMPULAN DAN SARAN}

A. Simpulan

Partisipasi masyarakat lokal dalam aktivitas desa wisata Jatiluwih dilihat atau diukur dari dua perspektif yaitu partisipasi masyarakat melalui pengambilan keputusan dan manfaat yang diterima masyarakat.

1. Dalam pengambilan keputusan masyarakat mendapat kesempatan mendengar dan didengarkan namun belum tentu pendapat mereka dipertimbangkan.

2. Pembagian manfaat pariwisata bagi masyarakat lokal di Desa Jatiluwih yaitu masyarakat sudah mulai merasakan manfaat dalam pembagian hasil dari pengembangan desanya. Selain itu juga memberi dampak terhadap bidang ekonomi yaitu lapangan pekerjaan dan kesempatan berusaha.

B. Saran

Berdasarkan analisis terhadap permasalah pada penelitian ini, hal hal yang dapat direkomendasikan antara lain :

Untuk pemerintah Kabupaten Tabanan, setelah penetapan subak Desa Jatiluwih sebagai situs warisan budaya dunia hendaknya perlu diberikan pendampinganan agar Subak Desa Jatiluwih tetap terjaga keasriannya. Selain itu pemerintah Kabupaten Tabanan hendaknya secara konsisten memberikan dukungan dan pendampingan seperti pelatihan-pelatihan dan sosialisasi program-program kepariwisataan agar masyarakat lokal secara keseluruhan lebih memahami pariwisata berkelanjutan dimana partisipasi mereka secara aktif memiliki peranan yang penting.

Untuk pengelola Daya Tarik Wisata Jatiluwih melibatkan pemilik sawah yang tidak dijadikan jalur trekking agar tetap dapat dilibatkan dan mendapatkan manfaat dari kegiatan pariwisata secara optimal. Upaya yang dapat dilakukan yaitu perlu memberikan pelatihan pelatihan dalam bidang kewirausahaan meliputi cara mengelola, menyajikan, pengemasan dan pemasaran produk wisata. Pihak Pengelola Daya Tarik Wisata Jatiluwih agar dapat meningkatkan kemampuan kerja masyarakat Desa Wisata Jatiluwih dalam sektor pariwisata seperti dalam bidang akomodasi, restoran, pemandu wisata serta pelayanan dalam bidang hospitaliti lainnya. Upaya yang dapat dilakukan melalui kerjasama dengan akademisi dan praktisi pariwisata. Pelibatan masyarakat pada tahap pengambilan keputusan lebih ditingkatkan. Selain itu perlu dibuatkannya Atraksi tambahan agar wisatawan bisa lebih lama tinggal di Desa jatiluwih seperti wisatawan diajak untuk memanen padi dan diikutsertakan untuk membajak sawah.

Untuk Masyarakat Desa Jatiluwih, sebagai pemilik daya tarik wisata, harus mampu berperan aktif dalam pengembangan desa. Partisipasi masyarakat sangat diperlukan agar pariwisata di Desa Jatiluwih berkelanjutan. Selain itu agar masyarakat dapat menerima manfaat dari pengembangan desa wisata. Masyarakat Desa Jatiluwih harus mempertahankan pengakuan WBD dengan cara menahan diri untuk tidak melakukan alih fungsi lahan pertanian pada kawasan yang ditetapkan sebagai WBD oleh UNESCO. Masyarakat harus mampu berpikir kreatif untuk dapat menyajikan keunikan yang terdapat di Jatiluwih seperti beras merahnya agar bernilai jual lebih dengan dibuat teh beras merah sebagai souvenir khas Desa Jatiluwih.

Perlu dilakukan penelitian lanjutan mengenai strategi peningkatan partisipasi dalam pengambilan keputusan untuk meningkatkan peran masyarakat dalam pengambilan keputusan di Desa jatiluwih, terutama dari aspek yang belum diteliti dalam penelitian ini. 
Vol. 6 No 1, 2018

\section{DAFTAR PUSTAKA}

Kementerian Pariwisata dan Ekonomi Kreatif. 2011. Desa dan Budaya dalam Bingkai Pariwisata. Jakarta: Pusat Penelitian dan Pengembangan Kepariwisataan.

Mukhtar. 2013. Metode Penelitian Deskriftif Kualitatif. Jakarta : GP Press Group

Nuryanti, Windu. 1993. Concept, Perspective and Challenges. Naskah Lengkap Laporan Konferensi Internasional mengenai Pariwisata Budaya. Yogyakarta: Gadjah Mada University Press.

Pemerintah Kabupaten Tabanan. 2006. Monografi Desa Jatiluwih

Penebelofficer. 2015. Desa Jatiluwih. Tabanan. (dikutip dari : penebel.tabanankab.go.id) diakses tanggal 20 Desember 2017

Prasiasa, Dewa Putu Oka. 2010. "Pengembangan Pariwisata dan Keterlibatan Masyarakat Di Desa Wisata Jatiluwih Kabupaten Tabanan" (disertasi). Denpasar: Program Pascasarjana Universitas Udayana

Sugiyono. 2014. Metode Penelitian Kuantitatif, Kualitatif dan R\&D. Bandung: Alfabeta.

Tikson, Deddy T. 2001. Partisipasi Masyarakat dalam Manajemen Perkotaan. Makassar.

Timothy, D. J. 1999. "Participatory Planning a View of Tourism in Indonesia" Annals of Tourism Research. Vol. 26(2).

Widari, Dewa Ayu. 2015. Perkembangan Desa Jatiluwih Setelah Penetapan Subak Sebagai Warisan Budaya Dunia di Kecamatan Penebel Kabupaten Tabanan. Denpasar: Program Pascasarjana Universitas Udayana 